\title{
(Un)Settling the West Bank of Israel/Palestine: the anthropology of citizenship in "no man's land"
}

\author{
By Yarden B. Enav-Weintraub (University of Edinburgh)
}

This paper answers Yael Navaro-Yashin's (2003) call for ethnographic research of "no man's land(s)", and to the ethnographic challenge she poses in her call for anthropologists to "sense the political" in such territories. The paper is based on my fieldwork in an Israeli college in the "West Bank" of Israel/Palestine and deals with the ambiguous political status of this geopolitical territory. The paper analyses the "West Bank" of Israel/Palestine as a (political) "no man's land" and attempts to "sense the political" there, with special emphasis on the changing status of Israeli citizenship in the "West Bank". In the end, the paper also suggests that anthropologists should pay more attention to the possibility that citizenship in a "normal" (nation-)state becomes the new locus where people today negotiate ideas about the political.

In this paper I will attempt to explore how people's lives, minds and the status of their Israeli citizenship changes when entering into the territory of the "West Bank" of Israel/Palestine. It is an attempt to "sense" as well as to observe the "political" in the "West Bank" territory. My 20-month period of fieldwork, on which this paper is based, was carried out in the ACJS (the Academic College of Judea \& Samaria), an Israeli college located in Ariel, a Jewish-Israeli settlement (or, more accurately, a "settlement-town" of almost 20,000 residents) in the middle of the "West Bank". I was on fieldwork from October 2004 to August 2006. By the time of writing, the college had already changed its name to Ariel University Centre (after its status as "university-to-be" was approved by the Israeli government). However, in this paper I will use the name ACJS whenever referring to this college. During the first few months of my fieldwork I taught in the college two or three times a week. Later, when I owned a car, I moved into the "settlement-town" of Ariel itself. In my research I was interested in the way people live and experience their life, their "Israeliness" and their Israeli citizenship in such a liminal political territory, a political territory that legally does not belong to any recognized "state".

I would like to open with an excerpt from my field notes, which I shall return to at the end of this paper.

I met Riad on a bus from Tel Aviv to Ariel College, when he asks me to sit next to him (it is a 1.5 hours ride). Riad is one of my students and a Palestinian citizen of Israel. He comes from a village in Northern Israel, and today he lives in the Ariel College dormitories. He is a young man of 22, and speaks Hebrew quite well, though with a heavy accent. He then starts to complain about the "high academic standards" in Ariel College (compared with another Israeli college in Acre, where he was studying before). He liked living in Acre better, where one, as he tells me, "could go to the beach and eat falafel and not really care about studying". In Ariel, he says, "there is nothing to do but studying". However, Ariel College gives a more personal 
treatment to students, in his words. I wonder to myself what made him, a Palestinian citizen of Israel, choose to study in this college, located in the middle of the "West Bank" of Israel/Palestine, instead of any other college in "Israel proper" (within the "Green Line"). As if he read my mind, Riad tells me of a girl he once met on a bus, who recommended Ariel College to him. He does not tell me more than that. (Field notes)

\section{The "West Bank" of Israel/Palestine: a (political) "no man's land"}

Up until 1948 the "West Bank" was one of the territories under British Mandate. Between 1948 and 1967 the "West Bank" was under Jordanian rule (though Jordan did not officially relinquish its claim to the territory until 1988, when the Palestine Liberation Organisation, PLO, declared from Algeria that the state of "Palestine" had been established). In 1967 Israel captured the territory, but never annexed it (with the exception of East Jerusalem). The term "West Bank" (referring to the west bank of the river Jordan) was apparently first used by the Jordanians after their annexation of the territory in 1948 (the Kingdom of Jordan being the "East Bank" of the river Jordan).

Newman tells us that:

The West Bank is a political, rather than a physical unit, brought about by the ceasefire lines following the 1948 War of Independence and the Armistice Agreement between Israel and Jordan. Excluding East Jerusalem, the area encompasses some 5,505 sq. km. (Newman 1982:7)

Thus since 1967 the "West Bank" of Israel/Palestine has been an ambiguous and contested geo-political entity, which up until today is not considered according to international law to be de jure part of any recognized state. Unrecognized as part of Israel, Jordan or any other "normal" (nation-)state, the "West Bank" qualifies in my eyes as a good example of what Navaro-Yashin (2003) calls (political) "no man's land". (While this is obviously a gendered term, I shall leave it as is, since in many ways it is also an appropriate reflection of gendered power relations in the dynamics surrounding the "West Bank".)

In her article "Life is dead here: Sensing the political in no man's land", Yael NavaroYashin (2003) introduces her concept of (political) "no man's land" through the example of the TRNC (Turkish Republic of Northern Cyprus), a "self-proclaimed state", established in Northern Cyprus under the auspices of Turkey as a result of a fatal war, which changed the government of this seemingly peaceful Mediterranean island in the 1970s. The "abnormal" political situation of the TRNC as a "phantom" or "pseudo" state results in the ambiguous political status of its inhabitants and of their citizenship. She therefore proposes "no man's land as a metaphor for an abjected space outside the recognized domains of the international system" (Navaro-Yashin 2003:103). Such a political territory, unrecognized as a state in its own right by the international community, but also independent in many ways of any other state, creates a political "anomaly" within the global order of "legitimate" (nation-)states.

However, as Navaro-Yashin explains, the intention behind carrying out research in such an "abnormal" political field is not to legitimise an "illegal" state, but rather to allow us to contemplate so-called "normal" (or "legal") states, what we consider to be "politically normative" and why. The phenomenon of political "no man's land(s)" challenges our political imagination, it questions and irritates our current understanding of "state" and "nation". Therefore, I agree with Navaro-Yashin when she suggests that more anthropologists should be doing fieldwork in (political) "no 
man's land". Some examples of such (political) "no man's land" in Europe could be the Transnistrian Moldovan Republic, the Nagorno-Karabakh Republic, Abkhazia in the Caucasus, and Northern Ireland/Ulster. Examples from Asia are the Tibet Autonomous Region and Kashmir.

As mentioned before, the 1967 war left the "West Bank" of Israel/Palestine in a political "limbo". It is as if in 1967 the "West Bank" territory was freed from the internationally recognized structure of "nation-states". Thus, it could be said that the 1967 war transformed the "West Bank" into, to use Victor Turner's (1992) terms, a "marginal" geo-political territory. Caught between two internationally recognized states (Israel and Jordan), the "West Bank" became, and has since been, an anomalous political "anti-structure". In The Rites of Passage Arnold Van-Gennep (1960) also mentions similar "neutral" territorial zones, which according to him have "magicoreligious" qualities to them.

As for the "West Bank" residents, the "West Bankers", they have entered a stage of political "liminality". The inhabitants of the "West Bank" were and still are, to use Turner's words again, "betwixt and between established states of politico-jural structures" (Turner 1992:49). To complicate the matter even further, in the "West Bank" there reside mainly "Palestinians" and (Jewish) "Israelis", two endogamous groups who struggle for hegemony over this one geo-political territory, believed by each of them to be part of its "national" homeland (and we should not ignore the "Samaritans", a tiny ethno-religious group of a few hundreds, who live in the area of Gerizim Mountain in the "West Bank").

One of the Jewish-Israeli students whom I interviewed at the ACJS told me: "I am Israeli because I was born here. I could leave, but I love the land... Being a settler in the Samaria today means that one loves the land." The quarter of a million JewishIsraeli settlers in the "West Bank" territory call it Yehuda VeShomron (Judea \& Samaria) or YOSH (the Hebrew acronym for Judea \& Samaria) and consider it to be the heartland of the biblical "Land of Israel" (also called Zion or Cana'an) and the "cradle of the Jewish nation". YOSH, rather than the Hebrew Hagada HaMa'aravit (West Bank), is the name widely used today in Israel, and also in official Israeli publications and by most of the Israeli public. However, for the more than two million Palestinian majority of the "West Bank", this territory is still part of Falastin (Palestine), the land they lost in the 1948 war to the Jewish-Israeli Zionist settlers.

\section{Physical and mental geographies in the "West Bank"}

The "West Bank Barrier" is also known by many other names, such as the "Security Fence", the "Separation Fence", and the "Apartheid Wall". Israel started to build this barrier in 2002 for "security reasons". That is, the official reason given for the building of the barrier was that the state needed to protect itself from the threat of Palestinian "suicide bombers". In the face of the mayhem and terror that Palestinian "suicide bombers" created within Israel, the decision was widely supported by the Israeli public. Thus, the building of the "West Bank Barrier" is a symbol of the victory of the discourse of "security" over the "human rights" discourse in Israel.

For most of its length the "West Bank Barrier" is indeed a "fence" (a barbed-wired fence, with trenches and electronic surveillance equipment), but in some areas (mainly within the city of Jerusalem) it is made up of a concrete wall. Currently, the barrier is more than $700 \mathrm{~km}$ (about 450 miles) long and still under construction (its current 
length being about $70 \%$ of the construction length approved by the Israeli government). Officially built for "security" reasons, the fence also separates the two communities living in the "West Bank" ("Israelis" and "Palestinians") and restricts Palestinians' freedom of movement within the "West Bank". The trail of the fence also does not completely follow the "Green Line" (the 1967 armistice line). Instead, it creates a new and different line, which could certainly become a de facto border in the future. A prominent example of that is the decision to leave the Ariel settlement-town (located in the middle of the "West Bank" territory) and its surrounding areas on the "Israeli side" of the fence.

The building of the fence along this new line ignores the 9/7/2004 decision of the International Court of Justice in the Hague, which deemed this to be a violation of human rights, as well as similar warnings by Israeli NGOs (such as the Be'Tzelem organization, URL 1). According to such warning reports, the fence separates Palestinians from their lands and olive groves and encircles Palestinian territories in a way that does not enable envisaging a viable Palestinian state or even normal Palestinian community life in the near future. Glen Bowman (2004) termed the rationale behind the barrier as the logic of "encystation". It is as if the Palestinians in the "West Bank" are enclosed into an "embryo-like" state, where they are both protected from the outside, but also are unable to develop independently. However, not only does the barrier physically separate the two populations of the "West Bank", it also establishes a mental separation. Yaron Ezrahi imagines Israelis and Palestinians in the "West Bank" as "Siamese twins". He thinks that "the wall made a lot of sense to people as a way to separate the two populations, and actually also create a distance, a mental distance between Arabs and Jews" (URL 2). And Dan Rabinowitz says about the barrier that it is "for many Zionists the demarcation line between them and the Palestinians [...] tantamount to the border between 'Europe' and 'Asia', civilization and barbarism, good and evil" (Rabinowitz 2003:4).

This is the place to consider both the physical and "mental" geography that has been created in the "West Bank" since 1967. There are more than 100 "authorised" (by the Israeli government) settlements in the "West Bank" and about 100 smaller "unauthorised" ones. The "West Bank" has about 4,500 km of roads, 2,700 km of which are paved, on some of which Israel maintains military checkpoints. Many of the roads Israel built in the "West Bank" are called Kevishim Okfim (bypass roads). These roads criss-cross the "West Bank" in order to connect all the Jewish-Israeli settlements together. The circling fences around the Jewish-Israeli settlements, the "bypass roads" system, the military checkpoints, and the newly-built "West Bank" barrier all join together to form a geographical structure, ultimately separating Israelis and Palestinians who live in the same geo-political territory. Thus what was created in the "West Bank" is not only a different physical structure of opportunities for the two populations (the roads one can take, the time it takes to get from place to place), but also a different mental structure, which I term a "mental geography of avoidance". That is, the physical geography created in the "West Bank" leads to two sets of "mental geographies", two different cognitive worlds, one for the Israeli settlers in the "West Bank" and another for its Palestinian residents. These are two parallel cognitive worlds in which Israelis and Palestinians almost never meet, even when they can physically see and hear each other.

The bypass road to Ariel, where the ACJS is located, is described as follows by one "mainstream" Israeli college information website: 


\begin{abstract}
Whoever wishes to drive to the Judea \& Samaria College today will do so on the new "Road no. 5". Unlike in the past, there is no need to go through Arab villages to remind you where you are. It is a highway that goes straight out of the heart of Israeli consensus in Gush Dan [the Tel Aviv area], where one right turn also takes one to the [political] right of Israeli society. One checkpoint at the entrance to Ariel, a town in the middle of the Samaria, and another one on your way back to Israel within the Green Line reminds you that you have just visited a college, which is not only a college, but also a political agenda. (URL 3, my translation)
\end{abstract}

Whoever wishes to go to the ACJS from Tel Aviv or Jerusalem should preferably own a car. In contrast with the old road to the settlement-town (which went through the Arab-Palestinian villages in the area), the new road to Ariel, built by clearing away age-old olive groves, allows one to arrive there in less than one hour. This new fourlane road could best be described as a "highway" (in Israeli terms). Though sometimes referred to as "Route 5", it is more widely known in Israel as Kevish Hotze-Shomron, the "Cross/Trans-Samaria" road. The road's name also carries political symbolism. By calling the road the "Cross/Trans-Samaria" road one is claiming that the "West Bank" lands are in the region of "Samaria", the heartland of the biblical Israelite Kingdom and what is considered to be the "cradle of the Jewish nation". Adding to this somewhat Orwellian atmosphere while driving from "Israel proper" and into the "West Bank" is the fact that nowhere on the road is there a sign that one has entered a different territory - besides one small military checkpoint (which a few months after my fieldwork turned into a much larger checkpoint, guarded by a watch-tower), where IDF (Israeli Defence Forces) soldiers stop "incoming" vehicles on their way back from the "West Bank" and into "Israel proper". The soldiers only check those who "enter" Israel. Thus, for Israeli citizens traveling from the Tel-Aviv area to Ariel, it does not seem as if they had crossed any sort of "border" or entered a different territory.

One day I was on my way from Ariel to Tel Aviv when I saw that two big yellow signs with writing on them (one in Hebrew and one in Arabic) had been put up by the side of the road where one enters "Israel proper":

Welcome to the Cross-Samaria checkpoint. This pass is restricted for Israelis only. It is forbidden for non-Israelis to pass (or to be transported) through this pass.

And the sign goes on to specify:

An Israeli - a resident of Israel, who lives in the area and is an Israeli citizen, or who is entitled to Israeli citizenship by the Law of Return 1950, or someone who is not a resident of the area but holds a permit [to enter Israel].

As this sign shows, the separation between Israelis and Palestinians in the "West Bank" is also and mainly a legal-political separation between citizens and "noncitizens". It seems that the fact of having (or not having) Israeli citizenship becomes the most salient criteria in order to determines one's political status within the "West Bank", and thus such older categories as "ethnic" (Jew/Arab) or "national affiliation" (Israeli/Palestinian) has become less important. That is, Israeli citizens acquire a privileged status when entering the "West Bank". Thus, I found that as different as it might be from the TRNC, the "West Bank" qualifies in my eyes as a good example of a "liminal" political zone, a "no man's land". It follows that in the "West Bank", as in the TRNC, the meaning of holding citizenship in a recognized state (or not holding it, for that matter) changes when entering this territory. This situation is not, however, 
unique to the "West Bank" of Israel/Palestine. This is only one example of a "liminal" and "abnormal" geo-political territory, a political "no man's land", which could potentially teach us more about the importance of citizenship in our global system of (nation-)states. This I intend to explore below.

\section{Israeli "privileged” citizenship}

In Israel, which is an "ethnic democracy" (Smooha 2002) with a Jewish majority, there are actually two "kinds" of Israeli citizens and "citizenships" today (perhaps not in the legal sense, but certainly in the sense of political statuses and social privileges). Though there is no direct discrimination against "non-Jews", there are certainly many privileges that favour Jews in the State of Israel, leading to a "dual" or "differential" system of citizenship: "Regular" citizenship for non-Jews and what I call "privileged (Jewish) citizenship" for Jewish-Israelis. The most prominent example of this is the 1950 "Law of Return" ("Hok HaShvut" in Hebrew), which combined with the "Nationality Law" of 1952 privileges only Jews with automatic Israeli citizenship at the moment of their immigration ("Aliya") to Israel.

As for the West Bank of Israel/Palestine, it could much more easily be said that two populations with two different political statuses reside there: (Jewish-) Israeli "citizens" and (non-Jewish) Palestinian "non-citizens". Since Palestinians in the West Bank (currently under Israeli military control) do not have Israeli citizenship at all (not even the underprivileged "regular" Israeli citizenship), the effect of the "privileged (Jewish) citizenship" in the West Bank is even more noticeable. The "bypass roads" are reserved for Jewish-Israelis only, the military check-points allow Israeli citizens to cross freely while detaining Palestinian drivers; all these practices mark this political differentiation. Finally, the West Bank barrier ultimately creates a citizenship-based physical separation between the two populations (Jewish Israeli "citizens" and Palestinian "non-citizens").

\section{Sensing the political in the "West Bank"}

This state of affairs in the "West Bank" has implications not only for the inhabitants of such a territory, but also for the anthropologist who studies them. During my own fieldwork in the "West Bank" of Israel/Palestine, and very much related to its "liminal" political status as "no man's land", I found that classical methods of participant observation were somewhat limited and limiting in my attempts to describe what it feels like to "be there". Though the "political" was sometimes visible (in the form of military checkpoints, for example), it was more frequently absent, leaving one with only a "sense" of it. It seems to me that it was similar methodological challenges and considerations in the TRNC that led Navaro-Yashin to claim that the anthropologist in "no man's land" should "sense", rather than observe, the political. In "no man's land", so we are told, the "natives" might claim to live a "normal everyday life". However, the anthropologist should "sense" the political context underneath the surface, she tells us. In her own words, the ethnographic mission is that of "sensing the catastrophe that underlies the pretense (or ideology) of "normal everyday life" (Navaro-Yashin 2003:109). In the "West Bank" the political catastrophe is omnipresent, and it is a catastrophe of both Israelis and Palestinians, both Jews and Arabs. Sometimes it seemed to me as if the Jewish-Israeli settlers were also "natives", in the sense that it was they who ignored the catastrophe of the "West 
Bank" and its political "abnormality", and continued with their "normal everyday life".

One day I was talking to Dorit in her house in Ariel settlement about current affairs, when she claimed that a war between Judaism, Christianity and Islam is at the heart of it all. In her words, the world is full in Anti-Semitism. The Holocaust, she said, was a punishment by God and, "Am Yisrael" [the Jews] must understand God's message and therefore never give up any part of the land. In her eyes, the state of Israel is nothing but an "artificial creation" and only the Jewish people and the land are real. While saying all this, Dorit kept referring me to the Bible and other holy scriptures. She said that she trusted God, and so she waited for redemption. At this exact moment her dogs started barking frantically outside the house. We both went out to her garden only to find out that nothing had happened, and that her two small fox-like dogs were making a lot of noise about nothing. Dorit used this opportunity to proudly show me the new almond tree that she had planted in the garden. (Field notes)

Many of the Jewish settlers in the West Bank are waiting for the coming of the "Messiah". In Navaro-Yashin's words, they are living in a "permanent temporality", in "frozen time" (Navaro-Yashin 2003:121). Not only that, but since the 1967 war people in this "bisected space" are also living in a "fantasy state", waiting for it to become a (politically) "recognized state", either as a part of Israel or as a part of "Palestine".

I met Andrey through an old friend of mine. Andrey is a scientist. He left a good job in one of Israel's largest universities for a teaching position in a new department in Ariel College. He and his wife came to Israel from one of the former Soviet republics. A few years ago he was working in the US, and then he came back to Israel with his wife and their two children (a boy and a girl). When we meet at his home in Ariel, Andrey explains to us that he wanted his children "to have the homeland that he and his wife never had". He shows us his big new house (he only rented it for half a year, since he wasn't sure about this move...) and the small garden (where he planted fruit trees and vegetables). His wife made us a very big lunch (lamb, rice and vegetables). Afterwards, we have some tea and sweets. Andrey tells us that both his parents were teachers, and so he is thinking of "going their way". On the house walls there is a picture of his father and some pictures of snowy landscapes. Before we leave, Andrey mentions that he is still uncomfortable with crossing "The Green Line", and that last time he did so he felt that the soldiers in the check-point "Looked at me as if I am one of the settlers". "Why do they [the settlers] have to make all that noise in the media?" he complains to us. (Field notes)

From the above it could be understood that "sensing" the political is an ethnographic method that anthropologists might prefer to use when carrying out research in an "abnormal" political entity, a political "no man's land", and especially when informants pretend to live normal lives. The anthropologist should therefore "work against the normalizing discourses", even those of their informants. The intention of this method is to uncover "the disaster that underlies a seeming pretense to normality" (Navaro-Yashin 2003:108). It seems to me that what this means is that it is somewhat harder for anthropologists working in "no man's land" to convey to their readers what it feels like to "be there", and that anthropologists should beware of the temptation to (follow their informants and) "normalize disruptive experience" (ibid:109). 
The next example attempts to show how one world breaks into another to disrupt the "pretense of normalcy" in the West Bank.

One evening I take a walk around Ariel settlement-town, where the college is located. Ariel is a secluded settlement in the middle of the West Bank. It is located on one of the highest hilltops in the region, towering over all the other rocky hills in its area. At night, looking away to the hills around Ariel and beyond its surrounding security-fence, I could spot here and there some twinkling lights in the darkness and some white roofs on the hills below it, which reminded me that some other people live here. As I keep walking it gets darker, and I suddenly wonder what happens in the [Palestinian] villages below the settlement... looking at the flickering lights in the darkness, I am drawn to them... and suddenly I feel it... I feel it as if it comes from within my own body, and it is only when it reaches my ears that I realize the sound comes from the outside: "Allllla Huwa Akbar ["God is great", in Arabic]... Allllla!" calls the Muslim Muezzin, the person who is calling to prayer from the village mosque down below the hill... and his voice fills the air... (Field notes)

\section{Waiting for the Messiah in the "West Bank"}

One Friday morning I got into my small white Daihatsu to make my way back from the ACJS to Tel Aviv. I took the left turn on the way out of Ariel settlement-town (the right goes "deeper" into the "West Bank"), ignoring the always-present hitch-hikers (mostly young settlers) by the side of this crossroad and drove away. This highway to Tel Aviv cuts through Palestinian olive-groves and the general landscape. I drive a few more miles ahead to see a Palestinian man riding his donkey to the side of the road. Another few miles later I could see a group of young Palestinians crossing in the middle of the highway, running. (Field notes)

In her article "Nationalism and resistance: The two faces of everyday activism in Palestine during the Intifada", Iris Jean-Klein (2001) notes that during the period of the first Intifada (Palestinian uprising) some of her informants went through a process she calls "self-nationalization". She explains that a more literal understanding of the term "everyday life" draws our attention to the "nationalizing efficacy of ordinary people's daily exercises". The men I saw crossing the "Trans Samaria" highway were risking their lives in an attempt to reach the other part of their village, which had been cut into two by this newly-built road. It seems to me that here too an ordinary everyday activity such as crossing a road could be understood as an act of "self nationalisation". On some occasions, such a non-violent activity could become a strong protest movement. As the Buddhist monk Thich Nhat Hanh (2004) put it, writing about Israelis and Palestinians:

If you know how to organize a group that is peaceful and can flow together as a river - even if the group is small - than you can have peace in your country and your people, and the action you take can be entirely non-violent.

(Hanh 2004:114)

However, in the current political context, I could not escape the sad feeling that, while many of the Jewish-Israeli settlers in the "West Bank" were waiting for the "Messiah", which according to Jewish belief was to appear riding a white donkey, if he happened to be the Palestinian man riding his donkey along the side of the "TransSamaria" road, then no one would have noticed that he and his time has come to Israel/Palestine. 


\section{The "West Bank" and Israeli citizenship: some final words}

In the end, one should consider the paradoxical status of Riad, the student whom I met on the bus, as mentioned in the excerpt at the beginning of this article. Riad is a nonJewish Israeli citizen of the State of Israel, whose freedom of movement was equal to my own in the "West Bank" of Israel/Palestine. It seems that as if "by default", when entering the "West Bank", Riad's political identity as an Israeli "citizen" became more salient than any of his other possible "ethnic" (Arab), "national" (Palestinian) or gender (male) identities. Could that be another reason why he chose to study in the ACJS?

Be Riad's reasons to choose to study in the ACJS as they may, I suggest here that for us as anthropologists, and especially as political anthropologists, the category of "citizenship" holds rich and fertile ground for research (and perhaps more so than previous concepts, such as "ethnicity", "ethnic groups" or "national groups"), as it just might be that citizenship becomes the new locus where people understand and negotiate their identities in today's world. In my view, it is only by freeing ourselves of previous political conceptualisations that we might be able to understand better people's life in the "West Bank" and in other political "no man's land(s)" across the globe. Or, to put it in Adam Kuper's (1988:14) words, it is only "if we liberate ourselves [that] we might be able to free others".

\section{References}

Bowman, Glenn. 2004. About a wall. Social Analysis 48(1), 14-20.

Hanh, Thich Nhat. 2004. Peace begins here: Palestinians and Israelis listening to each other. Berkeley: Parallax Press.

Jean-Klein, Iris. 2001. Nationalism and resistance: The two faces of everyday activism in Palestine during the Intifada. Cultural Anthropology 16(1), 83-126.

Kuper, Adam. 1988. The invention of primitive society: Transformations of an illusion. London and New York: Routledge.

Navaro-Yashin, Yael. 2003. Life is dead here: Sensing the political in no man's land. Anthropological Theory 3(1), 107-125.

Newman, David. 1982. Jewish settlement in the West Bank: The role of Gush Emunim. Centre of Middle Eastern \& Islamic Studies Occasional Papers Series No. 16.

Rabinowitz, Dan. 2003. Borders and their discontents: Israel's Green Line, Arabness and unilateral separation. European Studies 19, 3-17.

Smooha, Sammy. 2002. The model of ethnic democracy: Israel as a Jewish and democratic state. Nations \& Nationalism 8(4), 475-503.

Turner, Victor. 1992. Variations on the theme of liminality. In Blazing the trail: Way marks in the exploration of symbols, ed. Edith Turner, 48-65. Tucson: University of Arizona Press.

Van-Gennep, Arnold. 1960. The rites of passage. Chicago: University of Chicago Press. 


\section{Internet and electronic sources}

URL 1: Be'Tzelem official website, www.bselem.org

URL 2: Ezrahi, Yaron. 2004. Interview with Elisabeth Fransworth, Online Newshour, www.pbs.org/newshour

URL 3: University and Colleges Rankings, www.campus-il.info/mosad/yosh

\section{Acknowledgements}

A previous version of this paper was presented in the Ruppin College staff seminar. I would like to thank the University of Edinburgh and Ariel University Centre, and especially Prof. Jonathan Spencer and Prof. Dan Soen for their generous scholarships which enabled this field research to take place as part of my Ph.D. research project.

\section{About the author}

Yarden B. Enav-Weintraub is currently completing his Ph.D. in Social Anthropology at the University of Edinburgh (School of Social \& Political Studies). His research follows the study of Israeli anthropology in one academic college in the West Bank of Israel/Palestine and introduces the concept of Israeliness as a "culture of citizenship". Yarden lives in Tel Aviv. He can be contacted at Y.Enav@sms.ed.ac.uk 